\title{
Analisis Nilai Karakter Permainan Tradisional Pada Buku Siswa Kelas 4 SD Kurikulum 2013
}

\author{
Nur Aisah \\ SDN Menguneng 01 \\ nuraisah19031993@gmail.com
}

\section{Article History}

received 3/12/2020

revised 17/12/2020

accepted 31/12/2020

\begin{abstract}
The purpose of this study was to determine the character values contained in traditional games in the 4th grade elementary school curriculum 2013. This study used a qualitative descriptive study with a phenomenological approach. This study describes events or phenomena with data in the form of words. Methods of data collection using observation and documentation. The data validity technique uses source triangulation. The data analysis technique uses data collection, data selection, conclusion drawing, and validation. The results showed that 13 traditional games in the 4th Grade Elementary School Student Book published by the Ministry of Education and Culture were gobak sodor, forts, engklek, kasti, marbles, tug of war, woodpeckers and insects, fish, frogs and lizards, hunters and the Javan rhinoceros., build punden terraces, gangsing, enggrang, and sepak takraw containing values of honest character, tolerance, discipline, hard work, creative, independent, democratic, respecting achievement, friendly/communicative, peace loving, social care, and responsibility.
\end{abstract}

Keywords: value character, traditional games, books grade 4 curriculum SD 2013

\begin{abstract}
Abstrak
Tujuan penelitian ini adalah untuk mengetahui nilai karakter yang terdapat pada permainan tradisional yang ada dalam buku siswa kelas 4 SD kurikulum 2013. Penelitian ini menggunakan penelitian deskriptif kualitatif dengan pendekatan fenomenologi. Penelitian ini menggambarkan peristiwa atau fenomena dengan data-data yang berbentuk kata-kata. Metode pengumpulan data menggunakan observasi dan dokumentasi. Teknik keabsahan data menggunakan triangulasi sumber. Teknik analisis data menggunakan pengumpulan data, seleksi data, penarikan kesimpulan, dan pengabsahan. Hasil penelitian menunjukkan bahwa 13 permainan tradisional pada Buku Siswa Kelas 4 SD terbitan Kementerian Pendidikan dan Kebudayaan yaitu gobak sodor, benteng-bentengan, engklek, kasti, kelereng, tarik tambang, burung pelatuk dan serangga, ikan, katak, dan kadal, pemburu dan badak Jawa, membangun punden berundak-undak, gangsing, enggrang, dan sepak takraw mengandung nilai karakter jujur, toleransi, disiplin, kerja keras, kreatif, mandiri, demokratis, menghargai prestasi, bersahabat/komunikatif, cinta damai, peduli sosial, dan tanggung jawab.
\end{abstract}

Kata kunci: nilai karakter, permainan tradisional, buku siswa kelas 4 SD Kurikulum 2013

Social, Humanities, and Education Studies (SHEs): Conference Series https://jurnal.uns.ac.id/shes

p-ISSN 2620-9284

e-ISSN 2620-9292

This work is licensed under a Creative Commons Attribution-ShareAlike 4.0 International License. 


\section{PENDAHULUAN}

Kasus-kasus tentang tindakan tidak berkarakter yang dilakukan anak-anak semakin merajalela. Banyak pemberitaan tentang tindakan tidak berkarakter yang dilakukan oleh anak-anak khususnya para pelajar. Contohnya, kasus kekerasan siswa SD di Bukittinggi yang diduga efek game dan film kekerasan (David:2014). Masih banyak kasus-kasus serupa yang sangat memprihatinkan dunia pendidikan.

Di kota-kota besar seperti Jakarta, Surabaya, dan Medan, tawuran sering terjadi. Data di Jakarta misalnya (Bimmas Polri Metro Jaya), tahun 1992 tercatat 157 kasus perkelahian pelajar. Tahun 1994 meningkat menjadi 183 kasus dengan menewaskan 10 pelajar, tahun 1995 terdapat 194 kasus dengan korban meninggal 13 pelajar dan 2 anggota masyarakat lain. Tahun 1998 ada 230 kasus yang menewaskan 15 pelajar serta 2 anggota Polri, dan tahun berikutnya korban meningkat dengan 37 korban tewas. Terlihat dari tahun ke tahun jumlah perkelahian dan korban cenderung meningkat. Bahkan sering tercatat dalam satu hari terdapat sampai tiga perkelahian di tiga tempat sekaligus. (David:2014)

Salah satu kejadian pada saat peneliti melaksanakan PPL adalah anak SD bermain Kartu Remi yang biasanya dimainkan oleh orang tua. Anak yang kalah harus mentraktir yang menang berupa makanan atau minuman di kantin, namun ketika ditegur anak tersebut mengatakan "tidak apa-apa Bu, kan cuma bermain kartu remi". Hal tersebut sangat memprihatinkan, karena di usia SD mereka sudah tahu permainan yang dilakukan oleh orang dewasa. Kasus-kasus yang telah terjadi menunjukkan bahwa karakter anak-anak sudah tidak sesuai dengan UU RI No. 20 Tahun 2003 tentang Sistem Pendidikan Nasional, khususnya pasal 3 yang menyebutkan bahwa pendidikan nasional berfungsi mengembangkan kemampuan dan membentuk watak serta peradaban bangsa yang bermartabat dalam rangka mencerdaskan kehidupan bangsa, bertujuan untuk berkembangnya potensi siswa agar menjadi manusia yang beriman dan bertakwa kepada Tuhan Yang Maha Esa, berakhlak mulia, sehat, berilmu, cakap, kreatif, mandiri, dan menjadi warga negara yang demokratis serta bertanggung jawab.

Peran keluarga, sekolah, dan masyarakat sangat penting dalam proses perkembangan anak, karena keluarga dan masyarakat adalah yang paling dekat dengan anak dan sekolah adalah tempat dimana anak mendapat banyak ilmu untuk bekalnya dimasa depan. Oleh karena itu, saat di sekolah Kepala Sekolah dan Guru bertanggung jawab atas tingkah laku yang dilakukan anak. Keluarga, sekolah, dan masyarakat harus mampu bekerja sama dalam pembentukan karakter anak.

Pembentukan karakter pada anak harus dilakukan sejak dini, karena karakter anak terbentuk mulai dari usia dini. Salah satu cara membentuk karakter anak adalah memperkenalkannya dengan permainan tradisional, karena permainan tradisional mengandung banyak nilai karakter positif.

Dharmamulya (dalam Susanti, Siswati dan Widodo:2010) menyebutkan bahwa ada beberapa nilai yang terkandung dalam permainan tradisional yang dapat ditanamkan dalam diri anak antara lain rasa senang, adanya rasa bebas, rasa berteman, rasa demokrasi, penuh tanggung jawab, rasa patuh dan rasa saling membantu yang kesemuanya merupakan nilai-nilai yang sangat baik dan berguna dalam kehidupan bermasyarakat.

Permasalahan yang ada saat ini adalah permainan tradisional sekarang ini sudah mulai hilang tergantikan oleh permainan modern seperti permainan yang terdapat pada telepon seluler, laptop, atau komputer. Permainan tersebut dilakukan anak secara individu. Sehingga pada akhirnya anak-anak akan mulai terpengaruh oleh sifat individualisme dan tidak bisa diajak bekerja sama. Oleh karena itu penting sekali mengenalkan anak pada permainan tradisional.

Permainan tradisional dapat memberikan alternatif yang berbeda dalam kehidupan anak, karena permainan tradisional dapat digunakan sebagai media yang 
tepat untuk membentuk kepribadian anak, oleh sebab itu keberadaan permainan tradisional hendaknya tetap dilestarikan. Salah satu pelestariannya adalah dengan memasukkan permainan tradisional dalam proses pembelajaran siswa di SD.

Proses pembelajaran akan lebih menarik apabila diselingi dengan permainan tradisional, karena selain untuk bersenang-senang permainan tradisional juga memiliki banyak nilai karakter yang dapat membentuk kepribadian siswa. Hal tersebut tentu saja menjadi alasan permainan tradisional dimasukkan dalam buku siswa kurikulum 2013 terbitan Kementerian Kebudayaan dan Kebudayaan.

Kurikulum 2013 adalah kurikulum yang diterapkan pada tahun pelajaran 2013/2014. Kurikulum ini adalah pengembangan dari kurikulum yang telah ada sebelumnya. Fadlillah (2014:16) menyatakan bahwa titik tekan pada kurikulum 2013 adalah adanya peningkatan dan keseimbangan soft skills dan hard skills yang meliputi aspek kompetensi sikap, keterampilan, dan pengetahuan. Kurikulum 2013 berusaha untuk lebih menanamkan nilai-nilai yang tercermin pada sikap dapat berbanding lurus dengan keterampilan yang diperoleh peserta didik melalui pengetahuan dibangku sekolah (Fadlillah, 2014:16). Dalam kurikulum 2013 digunakan buku pedoman untuk belajar siswa selama dikelas, yaitu Buku Siswa dari Kementerian Pendidikan dan Kebudayaan. Didalam buku tersebut terdapat berbagai materi yang akan dipelajari oleh siswa, termasuk permainan tradisional. Buku Siswa memuat berbagai permainan tradisional yang akan dilakukan oleh siswa.

Buku Siswa kelas 4 SD dari Kementerian Pendidikan dan Kebudayaan dipilih karena terdapat berbagai permainan tradisional. Nilai karakter yang terdapat dalam permainan tradisional tersebut tentu dapat berpengaruh dalam pembentukan karakter anak khususnya siswa kelas 4 SD. Oleh sebab itu dianalisis berbagai nilai karakter yang terdapat dalam setiap permainan tradisional yang ada di Buku Siswa kelas 4 SD dari Kementerian Pendidikan dan Kebudayaan. Jadi, judul penelitian ini dipilih untuk mengungkapkan berbagai nilai karakter yang terdapat dalam Buku Siswa kelas 4 SD kurikulum 2013 dari Kementerian Pendidikan dan Kebudayaan agar dapat diterapkan guru, khususnya guru kelas 4 SD dalam proses pembelajaran.

\section{METODE}

Metode penelitian adalah cara ilmiah untuk mendapatkan data dengan tujuan dan kegunaan tertentu. Penelitian ini menggunakan pendekatan penelitian kualitatif. Pendekatan kualitatif adalah penelitian yang dimaksud untuk memahami fenomena tentang apa yang dialami oleh subyek penelitian misalnya perilaku, persepsi, motivasi, tindakan, dll., secara holistik, dan dengan cara deskripsi dalam bentuk kata-kata dan bahasa, pada suatu konteks khusus yang alamiah dan dengan memanfaatkan berbagai metode alamiah ( Moleong, 2013: 6). Jadi dalam penelitian kualitatif tidak berupa angka-angka seperti halnya penelitian kuantitatif, melainkan berupa gambargambar, kata-kata dan bahasa.

Setting Penelitian dalam penelitian ini tidak dilakukan di lapangan (non eksperimen). Penelitian ini dilakukan dengan mengumpulkan sumber dan mengkaji serta mengumpulkan kajian pustaka.

Sumber data dalam penelitian ini berasal dari sumber tertulis berupa dokumen (buku-buku) yang masih ada kaitannya dengan penelitian yang akan dilakukan serta seluruh permainan tradisional yang terdapat dalam buku siswa kelas 4 SD kurikulum 2013 dari Kementerian Pendidikan dan Kebudayaan.

Data dalam penelitian ini berupa data tertulis yang mendeskripsikan cara bermain permainan tradisional yang terdapat dalam Buku Siswa kelas 4 SD kurikulum 2013 dari Kementerian Pendidikan dan Kebudayaan, serta deskripsi dari nilai karakter yang terdapat pada masing-masing permainan tradisional tersebut. 


\section{HASIL DAN PEMBAHASAN}

Data dalam penelitian ini adalah 13 permainan tradisional yang terdapat dalam Buku Siswa Kelas 4 SD Kurikulum 2013 terbitan Kementerian Pendidikan dan Kebudayaan. Dalam permainan gobak sodor terdapat nilai karakter jujur, tolerasi, disiplin, kerja keras, kreatif, demokratis, menghargai pestasi, cinta damai dan tanggung jawab. Permainan benteng-bentengan mengandung nilai karakter jujur, toleransi, disiplin, kerja keras, kreatif, demokratis, menghargai prestasi, bersahabat/komunikatif, cinta damai dan tanggung jawab. Permainan engklek mengandung nilai karakter jujur, toleransi, disiplin, kerja keras, kreatif, mandiri, menghargai prestasi, bersahabat/komunikatif, cinta damai, dan tanggung jawab. Permainan kasti mengandung nilai karakter jujur, toleransi, disiplin, kerja keras, kreatif, demokratis, menghargai prestasi, bersahabat/komunikatif, cinta damai, dan tanggung jawab. Permainan kelereng mengandung nilai karakter jujur, toleransi, disiplin, kerja keras, kreatif, mandiri, demokratis, menghargai prestasi, bersahabat/komunikatif, dan cinta damai. Permainan tarik tambang mengandung nilai karakter jujur, disiplin, kerja keras, kreatif, menghargai prestasi, cinta damai, dan bersahabat/komunikatif. Permainan burung pelatuk dan serangga mengandung nilai karakter jujur, disiplin, kerja keras, kreatif, menghargai prestasi, bersahabat/komunikatif, cinta damai, dan tanggung jawab. Permainan ikan, katak, dan kadal mengandung nilai karakter jujur, toleransi, disiplin, kerja keras, kreatif, mandiri, demokratis, menghargai prestasi, cinta damai, dan tanggung jawab. Permainan pemburu dan badak jawa mengandung nilai karakter disiplin, kerja keras, kreatif, bersahabat/komunikatif, dan cinta damai. Permainan membangun punden berundak-undak mengandung nilai karakter toleransi, disiplin, kerja keras, kreatif, demokratis, menghargai prestasi, bersahabat/komunikatif, cinta damai, dan tanggung jawab. Permainan gangsing mengandung nilai karakter jujur, toleransi, disiplin, kerja keras, kreatif, mandiri, demokratis, menghargai prestasi, bersahabat/komunikatif, dan cinta damai. Permainan enggrang mengandung nilai karakter jujur, disiplin, kerja keras, mandiri, menghargai prestasi, bersahabat/komunikatif, peduli sosial dan tanggung jawab. Pada permainan sepak takraw mengandung nilai karakter toleransi, disiplin, kerja keras, kreatif, demokratis, menghargai prestasi, bersahabat/komunikatif, cinta damai, dan tanggung jawab.

Berdasarkan paparan nilai karakter yang terdapat pada 13 permainan tradisional di Buku siswa terbitan Kementerian Pendidikan dan Kebudayaan dapat dilihat bahwa nilai karakter yang terbanyak adalah disiplin, kerja keras, kreatif, bersahabat/komunikatif, dan cinta damai, kemudian nilai karakter tanggung jawab, jujur, toleransi, demokratis, mandiri, peduli sosial, dan menghargai prestasi.

Nilai karakter jujur ada pada 8 permainan tradisional. Melalui karakter jujur, anak dapat dipercaya orang lain dan mempunyai rasa percaya diri serta membentukan konsep diri yang positif karena anak mampu mengungkapkan sesuatu sesuai dengan kebenaran. Hal ini sesuai dengan manfaat bermain untuk perkembangan aspek emosi atau kepribadian yang diungkapkan Tedjasaputra (2007:38) dimana kegiatan bermain yang dilakukan bersama sekelompok teman akan mempunyai penilaian terhadap dirinya tentang kelebihan yang dimiliki sehingga dapat membantu pembentukan konsep diri yang positif, mempunyai rasa percaya diri, dan harga diri. Nilai karakter toleransi ada pada 8 permainan tradisional. Melalui karakter toleransi maka anak mampu menghargai perbedaan antara dirinya dengan orang lain, sesuai dengan yang diungkapkan Tedjasaputra (2007:38) bahwa manfaat bermain untuk perkembangan aspek sosial dimana anak akan belajar berbagi hak milik, menggunakan mainan secara bergilir, melakukan kegiatan bersama, mempertahankan hubungan yang sudah terbina, mencari cara pemecahan masalah yang dihadapi dengan teman mainnya yang memiliki pendapat berbeda dengan dirinya. Nilai karakter disiplin ada pada 13 permainan tradisional. Teori psikoanalisa yang diungkapkan Sigmund Freud dalam 
Tedjasaputra (2007:7) bahwa bermain sebagai cara yang digunakan anak untuk mengatasi masalah. Dengan begitu melalui karakter disiplin anak akan terbiasa untuk berperilaku tertib dan patuh pada berbagai ketentuan dan peraturan yang ada, sehingga tidak akan terjadi suatu permasalahan saat bermain. Nilai karakter kerja keras ada pada 13 permainan tradisional. Melalui karakter kerja keras maka anak akan menyalurkan tenaganya untuk menunjukkan upaya sungguh-sungguh dan menyelesaikan tugas dengan sebaik-baiknya. Hal ini sesuai dengan yang diungkapkan Tedjasaputra (2007:38) bahwa manfaat bermain untuk mengembangkan aspek fisik dimana dengan bermain maka anak akan menyalurkan tenaga (energi) yang berlebihan sehingga dia tidak merasa gelisah. Nilai karakter kreatif ada pada 13 permainan tradisional. Melalui karakter kreatif maka anak dapat mengembangkan kreatifitas yang ada pada dirinya dan mampu bereksperimen sesuai dengan ide yang dimiliki. Ini sesuai dengan teori kognitif yang diungkapkan oleh Jerome Bruner dalam Tedjasaputra (2007:7) bahwa fungsi bermain sebagai sarana untuk mengembangkan kreatifitas dan fleksibilitas sehingga dia mampu bereksperimen dengan memadukan berbagai perilaku baru serta tidak 'biasa'. Nilai karakter mandiri ada pada 5 permainan tradisional. Melalui karakter mandiri maka anak tidak mudah bergantung pada orang lain, sehingga anak dapat menggunakan keterampilannya untuk hidup mandiri saat dewasa nanti. Hal ini sejalan dengan yang diungkapkan Tedjasaputra (2007:5) bahwa bermain adalah sarana latihan dan mengelaborasi keterampilan yang akan diperlukan saat dewasa nanti. Nilai karakter demokratis ada pada 8 permainan tradisional. Melalui karakter demokratis maka anak akan belajar untuk bersikap dan menilai sama hak dan kewajiban orang lain dan dirinya. Hal ini sesuai dengan pemanfaatan bermain oleh guru yang diungkapkan Tedjasaputra (2007:38) bahwa bermain dapat digunakan guru untuk membina hubungan baik dengan anak, karena selama bermain suasananya bebas maka anak merasa tidak takut untuk bermain bersama. Nilai karakter menghargai prestasi ada pada 12 permainan tradisional. Melalui karakter menghargai prestasi maka anak akan belajar mengakui dan menghormati keberhasilan orang lain. Nilai karakter bersahabat/komunikatif ada pada 13 permainan tradisional. Melalui karakter bersahabat/komunikatif maka anak akan mudah hidup didalam masyarakat karena dia mampu berkomunikasi, bersahabat, dan bekerjasama dengan orang lain. Hal ini sesuai dengan manfaat bermain untuk perkembangan aspek kognisi yang diungkapkan oleh Tedjasaputra (2007:38) dimana dengan bermain bersama teman sebaya maka anak akan lebih mudah berkomunikasi karena perlu memahami katakata yang diucapkan oleh teman-teman, mengemukakan keinginan, pendapat, serta keinginannya. Nilai karakter cinta damai ada pada 13 permainan tradisional. Melalui karakter cinta damai maka anak mampu untuk bertindak dan bersikap yang membuat orang lain merasa aman dan tenang atas dirinya. Ini sesuai dengan teori kognitif yang diungkapkan oleh Jerome Bruner dalam Tedjasaputra (2007:7) bahwa dengan bermain, yang lebih penting bagi anak adalah makna bermain dan bukan hasil akhirnya. Sehingga, menang atau kalah pada akhir permainan anak tetap menjaga kerukunan. Nilai karakter peduli sosial ada pada 1 permainan tradisional. Melalui karakter peduli sosial maka anak akan tanggap dan peka terhadap lingkungan sekitarnya. Ini sesuai dengan manfaat bermain untuk mengasah ketajaman penginderaan yang diungkapkan Tedjasaputra (2007:38) bahwa penginderaan mencakup penglihatan, pendengaran, penciuman, pengecapan, dan perabaan perlu diasah agar anak menjadi lebih tanggap atau peka terhadap hal-hal yang berlangsung di lingkungan sekitarnya. Nilai karakter tanggung jawab ada pada 9 permainan tradisional. Melalui karakter tanggung jawab maka anak akan melaksanakan tugas dan kewajiban yang seharusnya dilakukan oleh dirinya, masyarakat, dan lingkungannya. $\mathrm{Hal}$ ini sesuai dengan manfaat bermain untuk pengembangan aspek sosial yang diungkapkan oleh Tedjasaputra (2007:38) bahwa bermain juga sebagai media bagi anak untuk mempelajari budaya setempat, peran-peran sosial, dan peran jenis kelamin 
yang berlangsung di dalam masyarakat. Sehingga, anak akan bertanggung jawab menjalani perannya di dalam masyarakat. Berdasarkan penjelasan nilai karakter pada permainan tradisional maka diharapkan siswa kelas 4 SD tetap dikenalkan dan diajarkan permainan tradisional di sekolah.

\section{SIMPULAN}

Berdasarkan rumusan masalah, hasil penelitian dan pembahasan yang telah dilakukan maka dapat disimpulkan bahwa 13 permainan tradisional yang terdapat pada buku siswa kelas 4 SD kurikulum 2013 terbitan Kementerian Pendidikan dan Kebudayaan memiliki berbagai nilai karakter sesuai dengan cara bermainnya. Nilai karakter yang terdapat pada masing-masing permainan tersebut dapat membentuk karakter yang baik untuk anak. Nilai karakter yang terdapat pada 13 permainan tradisional tersebut diantaranya: jujur, toleransi, disiplin, kerja keras, kreatif, mandiri, demokratis, menghargai prestasi, bersahabat/komunikatif, cinta damai, peduli sosial, dan tanggung jawab. Dimana permainan gobak sodor memiliki 9 nilai karakter, permainan benteng-bentengan memiliki 10 nilai karakter, permainan engklek mengandung 10 nilai karakter, permainan kasti mengandung 9 nilai karakter, permainan kelereng mengandung 10 nilai karakter, permainan tarik tambang mengandung 7 nilai karakter, permainan burung pelatuk dan serangga mengandung 9 nilai karakter, permainan ikan,katak dan kadal mengandung 11 nilai karakter, permainan pemburu dan badak jawa mengandung 6 nilai karakter, permainan membangun punden berundak-undak mengandung 10 nilai karakter, permainan gangsing mengandung 9 nilai karakter, permainan enggrang mengandung 8 nilai karakter dan permainan sepak takraw mengandung 9 nilai karakter. Jadi dari 18 nilai karakter yang ditetapkan oleh Kementerian Pendidikan dan Kebudayaan nilai jujur terdapat pada 8 permainan tradisional, nilai toleransi terdapat pada 8 permainan tradisional, nilai disiplin terdapat pada 13 permainan tradisional, nilai kerja keras terdapat pada 13 permainan tradisional, nilai kreatif terdapat pada 13 permainan tradisional, nilai mandiri terdapat pada 5 permainan tradisional, nilai demokratis terdapat pada permainan tradisional, nilai menghargai prestasi terdapat pada 12 permainan tradisional, nilai bersahabat/komunikatif terdapat pada 13 permainan tradisional, nilai cinta damai terdapat pada 13 permainan tradisional, nilai peduli sosial terdapat pada 1 permainan tradisional dan nilai tanggung jawab terdapat pada 9 permainan tradisional.

\section{DAFTAR PUSTAKA}

Darmawan, Deni.2013. Metode Penelitian Kuantitatif. Bandung: PT Remaja Rosdakarya

Fadlillah, M. 2014. Implementasi Kurikulum 2013. Yogyakarta: Ar-Ruzz Media

Moleong, Lexy J. 2013. Metodologi Penelitian Kualitatif. Bandung: PT Remaja Rosdakarya.

Mulyani, Sri. 2013. 45 Permainan Tradisional Anak Indonesia. Yogyakarta: Langensari Publising

Samani, Muchlas. Hariyanto. 2013. Pendidikan Karakter. Bandung: PT Remaja Rosdakarya Offset

Setyawan, Davit. 2014. Kasus Kekerasan Siswa SD di Bukittinggi Diduga Efek Game dan Film Kekerasan. http://www.kpai.go.id/berita/kpai-kasus-kekerasan-siswa-sddi-bukittinggi-diduga-efek-game-dan-film-kekerasan/. Diakses pada 17 Desember 2014 pukul 22.15

Setyawan, Davit. 2014.Tawuran Pelajar Memprihatinkan Dunia Pendidikan.http://www.kpai.go.id/artikel/tawuran-pelajar-memprihatinkan-duniapendidikan/. Diakses pada 17 Desember 2014 pukul 22.17 
Soegeng, Abdullah, dan Kasihadi. 2013. Landasan Pendidikan Karakter. Semarang: IKIP PGRI Semarang Press

Sugiyono. 2010. Metode Penelitian Kuantitaif, Kualitatif Dan R \& D. Bandung. Alfabeta Supardi. 2013. Publikasi IImiah Non Penelitian dan Karya Inovatif. Yogyakarta: Andi Offset

Suwarjo. Eliasa, Imania. 2012. Permainan (Games) dalam Bimbingan dan Konseling. Yogyakarta: Paramitra Publishing

Suyadi. 2013. Strategi Pembelajaran Pendidikan Karakter. Bandung: PT Remaja Rosdakarya

Tedjasaputra.Mayke S. 2007. Bermain, Mainan dan Permainan untuk Pendidikan Usia Dini. Jakarta: PT Gramedia

Wardani, Dani. 2010. 33 Permainan Tradisional yang Mendidik. Yogyakarta: Cakrawala 